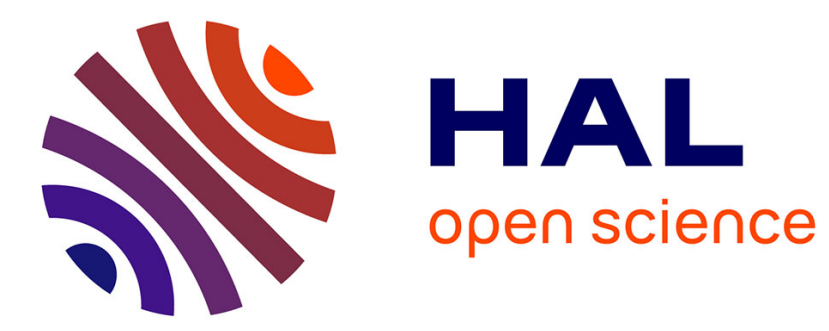

\title{
Microwave dielectric spectroscopy of individual electroporated cells
}

\author{
Amar Tamra, Katia Grenier, Marie-Pierre Rols, David Dubuc
}

\section{To cite this version:}

Amar Tamra, Katia Grenier, Marie-Pierre Rols, David Dubuc. Microwave dielectric spectroscopy of individual electroporated cells. 2021 XXXIVth General Assembly and Scientific Symposium of the International Union of Radio Science (URSI GASS), Aug 2021, Rome, Italy. pp.1-4, 10.23919/URSIGASS51995.2021.9560287 . hal-03407650

\section{HAL Id: hal-03407650 https://hal.laas.fr/hal-03407650}

Submitted on 28 Oct 2021

HAL is a multi-disciplinary open access archive for the deposit and dissemination of scientific research documents, whether they are published or not. The documents may come from teaching and research institutions in France or abroad, or from public or private research centers.
L'archive ouverte pluridisciplinaire HAL, est destinée au dépôt et à la diffusion de documents scientifiques de niveau recherche, publiés ou non, émanant des établissements d'enseignement et de recherche français ou étrangers, des laboratoires publics ou privés. 


\title{
Microwave dielectric spectroscopy of individual electroporated cells
}

\author{
A. Tamra ${ }^{(1,2)}$, K. Grenier* (1), M-P. Rols ${ }^{(2)}$, and D. Dubuc ${ }^{(1)}$ \\ (1) LAAS-CNRS, Université de Toulouse, CNRS, UPS, Toulouse, France, https://www.laas.fr/public/en \\ (2) IPBS-CNRS, Toulouse, France, http://www.ipbs.fr
}

\begin{abstract}
This paper illustrates the interest of analyzing electroporated cells with microwave dielectric spectroscopy. Different electroporation conditions have been applied on cells, for which individual microwave characterization leads to not only quantitative capacitive spectra with similar results as with the trypan blue standard viability test, but with a possible fine graduation of the electroporation impact on a cell population at the single cell level.
\end{abstract}

\section{Introduction}

Microwave dielectric spectroscopy is under development for decades. It consists in characterizing whether solid, liquid or gaseous materials with their dielectric properties in this specific frequency range. The technique is intrinsically non-destructive, rapid and without requiring a direct contact with the sample under test, which made it particularly attractive for its exploitation in many applicative domains, such as the detection of pipeline in the soil, coal in canalizations, as well as moisture sensing in agriculture areas, wood industry or for food quality assessments [1-3]. However, based on cumbersome microwave equipment, microwave dielectric spectroscopy has been for long limited to macroscale developments.

With the advent of the micro and nanotechnologies, new applicative opportunities have opened up in chemistry, biology and medicine notably. Due to the resonant frequency of the water molecules in the microwave band, the technique is particularly sensitive to biological materials, which naturally exhibit a high-water content. Combined with the use and the manipulation of small liquid volumes, this sensing technique has been successfully developed for molecular and cellular analysis [4-6]. The technique has been applied to tissues, cells suspensions and down to individual cells analysis [7, 8]. It was also demonstrated for cell quantification, identification and the monitoring of biological processes, while cells were maintained in their traditional environment, their culture medium. Attractively for cellular investigations, the sensing technique is also noninvasive and label free. And more interestingly, due to the employed high frequency range, the electromagnetic fields may bypass the capacitive cytoplasmic membrane and penetrate inside the cells, revealing quantitative information related to the intracellular dielectric activity. This spectroscopic method consequently appears suitable to analyze internal variations of cells, which notably involve water molecules interaction modifications.

To verify such an ability, different physical or chemical stimuli applied on various cell lines are investigated. Among them is the application of millisecond pulsed electric fields at different intensity levels on cell suspensions. This paper focuses on the microwave characterization of cells submitted to such fields at the single cell level, highlighting the features offered by characterizing the cells with microwave dielectric spectroscopy.

\section{Description of the microwave sensor dedicated to single cell measurements}

Figure 1 presents a photography of the microwave sensor, which is developed to perform the dielectric characterization of individual cells. Due to the presence of a mechanical trap in the middle of the sensor, only one cell may be blocked at a time and analyzed directly into its culture medium or any other host liquid.

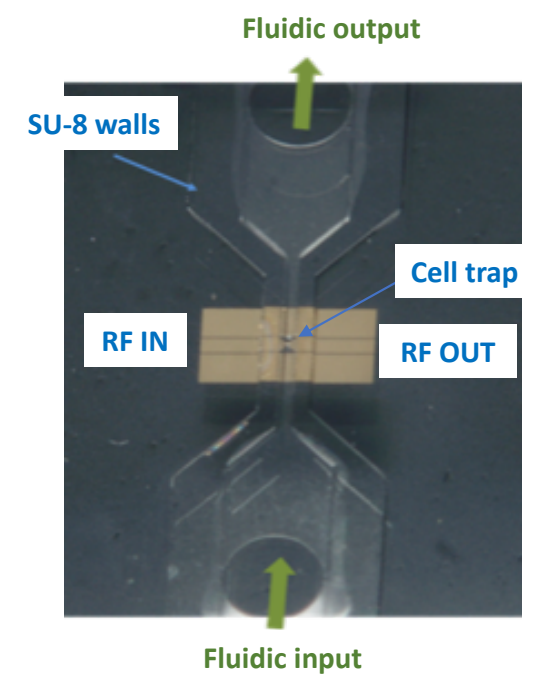

Figure 1. Photography of the microwave sensor suitable to individual cell measurement.

The sensing is performed through a coplanar waveguide, which integrates a capacitive gap on the central conductor. To maximize the sensitivity of the sensor, this gap exhibits a width of $5 \mu \mathrm{m}$ between two tapers.

RF measurements are performed with a Vector Network Analyzer, which is connected to the sensor through two 
coaxial cables and two coplanar probes. The input impedance of the line is $50 \Omega$. As the the sensor is realized on a quartz substrate, the central conductor and the slots are 150 and $15 \mu \mathrm{m}$ large respectively.

\section{Investigated cells and electroporation conditions}

The investigated cells are THP1 ones, which are coming from a human who presented an acute monocytic leukemia. These cells are cultured in the RPMI medium and presents a round shape, as shown in Fig. 2.

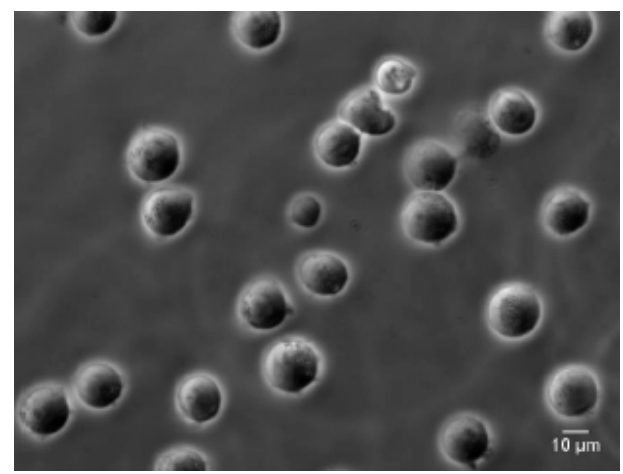

Figure 2. Photography of THP1 cells with optical microscope with 40x magnification.

The electroporation of the cells is performed through the test setup indicated in Fig. 3. It includes a high electric field generator (Electro cell S20 from Betatech) linked to parallel plate electrodes inside which the cells suspension is located.

After culture, cells are collected and placed in a ZAP buffer. $100 \mu \mathrm{L}$ is placed between the electrodes to be exposed to the electric field. After electroporation (EP), cells are kept intact for 5 minutes before transfer in a Petri dish for 24 hours in culture medium. After incubation, cells are centrifugated and placed in a fresh culture medium with a concentration of 1 million cells $/ \mathrm{ml}$.

Two electroporation conditions are used.

- One is chosen to obtain a reversible electroporation of the cells, using 8 pulses of $1 \mathrm{kV} / \mathrm{cm}$, pulse duration of 100 $\mu \mathrm{s}$, at a frequency of $1 \mathrm{~Hz}$. It permits to permeabilize around $90 \%$ of the cells with a survival rate of $70 \%$.

- The second and stronger condition leads to around 100\% of permeabilized cells with a low survival rate close to $50 \%$. 8 pulses of $1.5 \mathrm{kV} / \mathrm{cm}$, pulse duration of $100 \mu \mathrm{s}$, at a frequency of $1 \mathrm{~Hz}$, are used.

Permeability and survival rates have been evaluated with microscope counting, based on photographies indicated in Fig. 4.

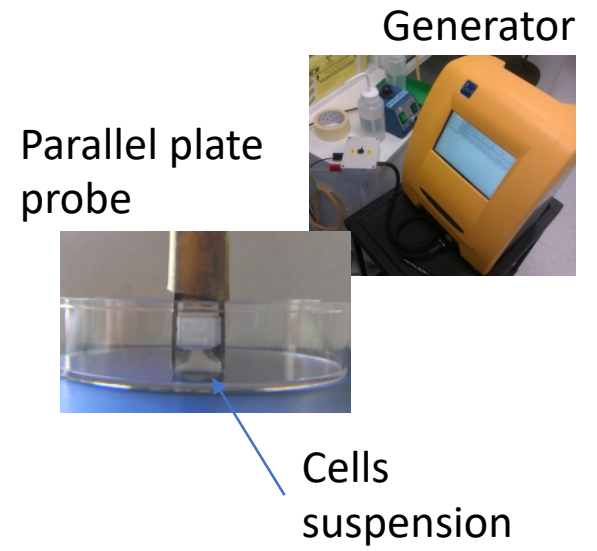

Figure 3. Electroporation setup.

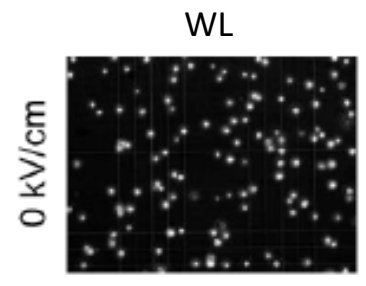

Fluorescence
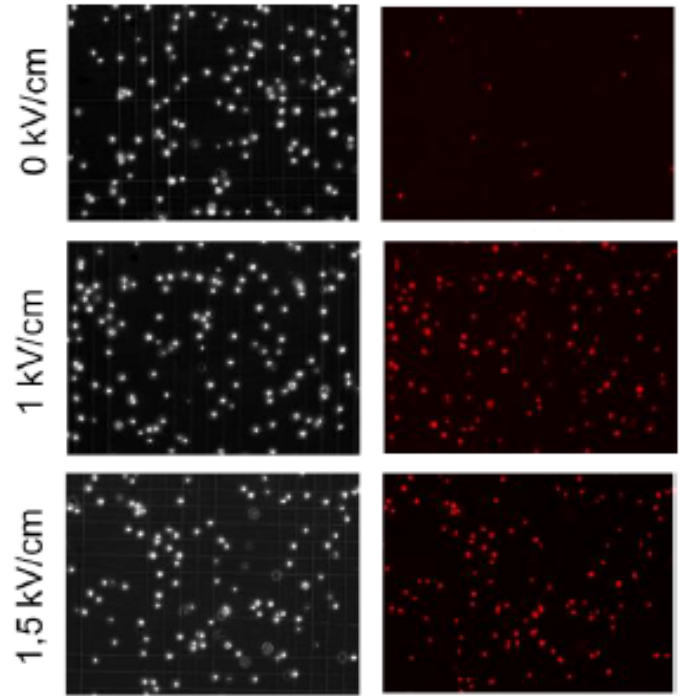

Figure 4. Permeability observed after electroporation in the presence of propidium iodide (PI), with different values of the electric field $(0,1$ and $1.5 \mathrm{kV} / \mathrm{cm}), 100 \mu \mathrm{s}, 1$ $\mathrm{Hz}, \mathrm{n}=8$. WL: in white light, FLUO: in fluorescence.

\section{Microwave characterization of individual electroporated cells.}

Microwave measurements are made on a frequency range from $40 \mathrm{MHz}$ to $40 \mathrm{GHz}$, and are continuously compared with a reference value (that of the RPMI culture medium), represented in dotted line in green on the graphs of Fig. 5.

Figure 5 represents the capacitive spectra of untreated THP1 cells (negative control), and subjected to $1 \mathrm{kV} / \mathrm{cm}$ and $1.5 \mathrm{kV} / \mathrm{cm}$, respectively. A reduced but representative number of cells is presented in these graphs, in order to give a general idea of the spectral behavior of the cells as well as the repeatability of measurement. 

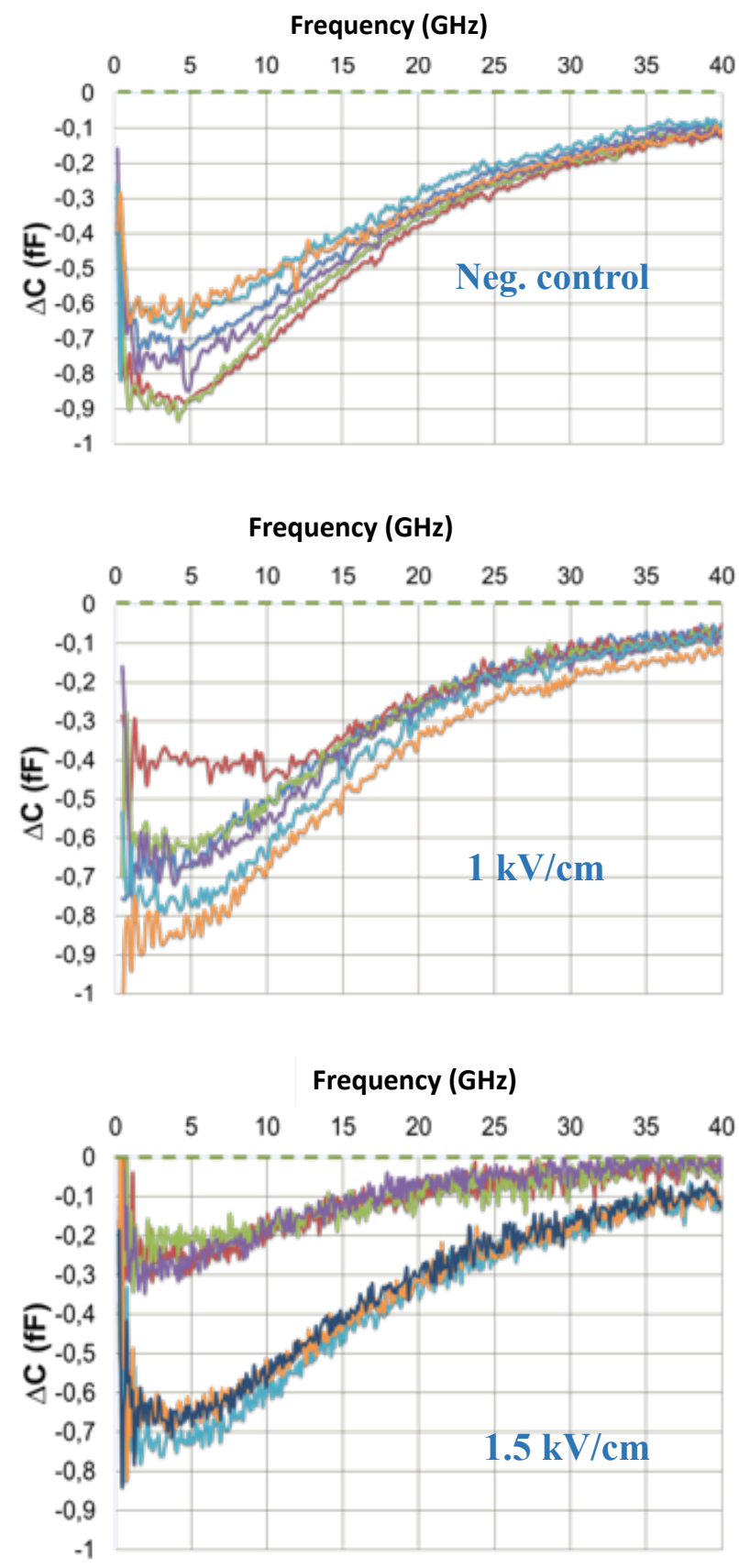

Figure 5. Capacitive constrats of individual cells : non treated or submitted to 1 or $1.5 \mathrm{kV} / \mathrm{cm}$.

By qualitatively comparing the spectra of pulsed cells to the spectra of negative control cells, we notice that, at 1.5 $\mathrm{kV} / \mathrm{cm}$, a decrease in absolute value of $\Delta \mathrm{C}$ for certain cells is observed. This creates a distinct separation between two cellular subgroups: living cells and cells affected by the electric field.

In order to consolidate our study, a quantitative study of the obtained results is made. Figure 6 shows the evolution of the value of the capacitive contrast, at the selected frequencies (at $5 \mathrm{GHz}$ ), as a function of the value of the EP field. Each point represents an analyzed cell and Figure 6 shows all of the measurements made. The graph shows the percentages of living and affected cells, according to an established threshold, based on cell survival with a chemical agent named saponine, and which allows cell classification. On the capacitive contrast parameter $\Delta \mathrm{C}$, the $\mathrm{EP}$ results in a decrease in viability compared to the control, which reaches $87 \%$ for cells pulsed at $1 \mathrm{kV} / \mathrm{cm}$ and $53 \%$ for cells pulsed at 1.5 $\mathrm{kV} / \mathrm{cm}$.

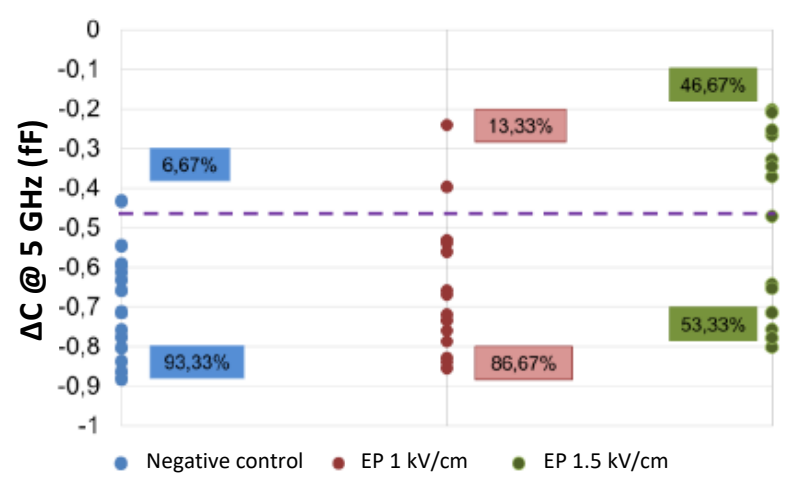

Figure 6. Quantitative measurements of the capacitive contrasts $\Delta \mathrm{C}$ at $5 \mathrm{GHz}$ of THP1 at different EP conditions.

These results have been compared to a standard test employed to evaluate the permeabilization of cells, the trypan blue, which colors the porated cells only. Similar results are obtained, i.e a viability close to $87 \%$ and $55 \%$ with $1 \mathrm{kV} / \mathrm{cm}$ and $1.5 \mathrm{kV} / \mathrm{cm}$ EP conditions respectively.

\section{Conclusions}

Microwave dielectric spectroscopy is used to dielectrically characterize electroporated cells. The technique leads to similar results in term of viability as the standard trypan blue test. However, the access to dielectric spectra leads to a further observation of the cells state. The reversible EP condition presents indeed a transient representation of the cells located between the untreated case and the strong EP condition, whereas THP1 cells submitted to $1.5 \mathrm{kV} / \mathrm{cm}$ exhibit a much distinct separation between two cell states.

Microwave dielectric spectroscopy consequently enables a fine graduation of the EP impact on a cell population at the single cell level.

\section{Acknowledgements}

This work was partly supported by the LAAS-CNRS micro and nanotechnologies platform of the French RENATECH network and by the Université Fédérale de Toulouse and the Midi-Pyrénées region.

\section{References}

1. K. Kupfer, "Electromagnetic aquametry," Springer, 2010. 
2. S. Trabelsi et al., "New calibration technique for microwave moisture sensors," IEEE T-Inst. And Meas. 2001, 50, 4, 877-881.

3. S. O. Nelson, W. Guo, S. Trabelsi, and S. J. Kays, "Sensing quality of watermelons through dielectric permittivity," Antennas and Propagation Society International Symposium, 2007 IEEE, 2007, pp. 285-288.

4. K. Grenier, D. Dubuc, P-E. Poleni, M. Kumemura, H. Toshiyoshi, T. Fujii, H. Fujita, 'Integrated Broadband Microwave and Microfluidic Sensor dedicated to Bioengineering', IEEE Trans. on Microwave Theory and Techniques, Vol. 57, n 12, Dec. 2009, pp. 3246-3253.

5. K. Grenier, D. Dubuc, T. Chen, F. Artis, T. Chretiennot, M. Poupot, J-J. Fournie, "Recent Advances in Microwave-based Dielectric Spectroscopy at the Cellular Level for Cancer Investigations," IEEE T-MTT, Vol. 61, Issue 5, Part 2, 2013, pp. 2023-2030.

6. E. Levy, G. Barshtein, L. Livshitz, P. Ben Ishai1 and Yu. Feldman, "The Vitality of Human RBC and its connection to cytoplasmic water: I. The glucose concentration influence" Journal Physical Chemistry B, 2016, 120, 10214.

7. X. Ma, X. Du, L. Li, H. Li, X. Cheng, J. Hwang, "Sensitivity Analysis for Ultra-wideband 2-port Impedance Spectroscopy of a Live Cell," IEEE Journal of Electromagnetics, RF and Microwaves in Medicine and Biology, June 2019, DOI: 10.1109/JERM.2019.2921221.

8. T. Chen, et al., "Microwave biosensor dedicated to the dielectric spectroscopy of a single alive biological cell in its culture medium," 2013 IEEE MTT-S International Microwave Symposium Digest, June 2-7, 2013, DOI: 10.1109/MWSYM.2013.6697740. 